Pak. j. sci. ind. res. ser. A: phys. sci. 2016 59(3) 130-143

\title{
Beneficiation Studies on Low-Grade Complex Polymetallic Lead-Zinc Ore of Duddar (Lasbela) Balochistan, Pakistan
}

\author{
Muhammad Arif Bhattia*, Kamran Raza Kazmi ${ }^{\mathrm{a}}$, Abdul Ahad ${ }^{\mathrm{b}}$, Anila Tabassum ${ }^{\mathrm{c}}$, \\ Rashid Mehmood ${ }^{\mathrm{a}}$ and Adnan Akram ${ }^{\mathrm{a}}$ \\ ${ }^{a}$ Mineral Processing Research Centre, PCSIR Laboratories Complex, Ferozepur Road, Lahore-54600, Pakistan \\ ${ }^{\mathrm{b}}$ Government Islamia College, Civil Lines, Lahore, Pakistan \\ 'Institute of Chemistry, University of the Punjab, Lahore-54590, Pakistan
}

(received January 23, 2015; revised August 6, 2015; accepted October 7, 2015)

\begin{abstract}
A bench-scale beneficiation study was performed on low-grade complex lead-zinc ore of Duddar area, District Lasbela, Balochistan Province, Pakistan. The polymetallic ore under investigation contains galena and sphalerite as valuable minerals of lead and zinc. The low-grade ore was upgraded by selective sequential froth flotation technology to recover both minerals. An effort was made to investigate the effect of important variables on grade and recovery of concentrates and to design the process flow sheet. Different parameters of flotation process such as particle size of the feed, $\mathrm{pH}$ and $\%$ solids of the pulp, speed of impeller, type of reagents (collectors, frothers, regulators and modifiers) and their quantities, conditioning time and flotation time were optimized to attain maximum grade and recovery of respective concentrates. The rougher concentrates obtained were subjected to one regrinding and two cleaning operations to achieve higher-grade concentrates of both metals. Bench-scale flotation tests show that it is possible to obtain a lead concentrate assaying $65.24 \% \mathrm{~Pb}$ with recovery rate of $81.32 \%$ and a zinc concentrate containing $55.63 \% \mathrm{Zn}$ content with recovery rate of $80.28 \%$. Both the concentrates meet the specifications required for metallurgical and chemical grades.
\end{abstract}

Keywords: low grade, lead-zinc ore, galena, sphalerite, beneficiation, froth flotation, grade, recovery

\section{Introduction}

Lead-zinc ore deposits are widely distributed throughout the world. In most primary ore deposits, galena $(\mathrm{PbS})$ and sphalerite $(\mathrm{ZnS})$ are the common minerals of lead and zinc, respectively. They generally occur together with sphalerite predominating but there are all gradations in relative proportions. Both may be oxidized to secondary minerals in the weathered zone of ore deposits. Galena generally oxidizes to cerussite $\left(\mathrm{PbCO}_{3}\right)$ and anglesite $\left(\mathrm{PbSO}_{4}\right)$. The common secondary zinc minerals are smithsonite $\left(\mathrm{ZnCO}_{3}\right)$, zincite $(\mathrm{ZnO})$, hydrozincite $\left[\mathrm{Zn}_{5}(\mathrm{OH})_{6}\left(\mathrm{CO}_{3}\right)_{2}\right]$, willemite $\left(\mathrm{Zn}_{2} \mathrm{SiO}_{4}\right)$ and hemimorphite $\left[\mathrm{Zn}_{4} \mathrm{Si}_{2} \mathrm{O}_{7}(\mathrm{OH})_{2} \mathrm{H}_{2} \mathrm{O}\right]$ also known as calamine. However, galena and sphalerite are the principal minerals explored for extraction of lead and zinc metals (Keqing et al., 2005). Both metals are utilized in production of various important commercial alloys. Lead also finds its use in lead storage batteries, whereas zinc is primarily used in galvanizing of iron and steel products. Thus, lead and zinc compounds are extensively used for various industrial applications.

Since high-grade ores are depleting worldwide, research studies involving the enrichment of low-grade ores are *Author for correspondence; E-mail: arifbhattipcsir@yahoo.com increasing. It is essential to obtain high-grade concentrates both in case of electrolytic and blast furnace processes because the cost of production rises steeply with the decrease in grade of the concentrate used for metal extraction. The mineralogy and texture of different ore deposits governs the process for their beneficiation. Generally, gravity based and froth flotation methods are adopted for beneficiation of low-grade lead-zinc ores. Sometimes, gravity methods are employed for ore pre-concentration followed by flotation (Atrafi et al., 2012). The texture of lead-zinc ores shows all variations from coarse-grained to extremely fine-grained. Since most of the lead-zinc ores are fine-grained and sulphide in nature therefore, concentrated mainly by flotation process. Oxidized ores may also be processed by flotation after sulphidization (Keqing et al., 2005).

The complex sulphides of lead, zinc and iron can be separated by flotation technique quite efficiently and effectively. The most common practice for processing of complex sulphide ores is the successive selective flotation of various sulphide minerals using specific flotation reagents and controlling various parameters (Day, 2002; Bushell and Testut, 1985). In some cases, mineralogy and metallurgical response favours an initial 
bulk lead-zinc concentrate which is subsequently separated into lead and zinc minerals in a selective flotation step. The separation of galena and sphalerite during production of zinc free galena concentrate and lead free sphalerite concentrate is the controlling factor in the processing of lead-zinc ores. Therefore, the maximum possible degree of separation in the concentrating plant is always prerequisite. De-zincing of lead concentrate and de-leading of zinc concentrate is also practiced in some commercial plants (Fairweather, 2005). The success of methodology depends upon not only the ore characteristics but also on the processing parameters which affect the designed route (Singh et al., 2009).

Many researchers investigated the role of different types of collectors i.e. dithiocarbonates, dithiophosphates alone and in different combination in bulk and selective flotation and reported their response. Silvestre et al. (2009) investigated the role of three important dispersants (sodium silicate, sodium polyacrylate and sodium hexametaphosphate) in the selective flotation of galena and sphalerite. Li and Zhang (2012), performed experimental study using flotation process on multi metal lead-zinc sulphide ore deposit which showed good separation of lead concentrate $(59.78 \% \mathrm{~Pb})$ with recovery of $87.50 \%$, and zinc concentrate $56.33 \% \mathrm{Zn}$ with recovery of $93.60 \%$. Yuan et al. (2012) investigated a refractory lead-zinc ore with high pyrite. Their experimental work is consisted of prior bulk $\mathrm{Pb}-\mathrm{Zn}$ flotation; reagent removal, regrinding of rougher concentrates and second selective flotation. The closed circuit tests could produce lead concentrate of $50.55 \%$ with recovery of $92.25 \%$ and zinc concentrate of $40.12 \%$ with recovery of $85.82 \%$.

The main objective of present investigation is to develop an economically feasible process for the concentration of indigenous low-grade lead-zinc ore of Duddar area. Comprehensive flotation studies have been carried out on lead-zinc ore samples at Mineral Processing Laboratory to produce lead and zinc concentrates with optimization of various process parameters to achieve maximum grade and recovery. A brief account of test work provides optimum conditions for concentrating the ore and the effect of change of process variables is being presented in this study.

\section{Materials and Methods}

Lead-zinc ore deposits of Pakistan. Potential leadzinc ore deposits have been reported to exist at various locations in Pakistan. The large and significant deposits are found at Besham, district Swat, in Khyber Pakhtoon Khwa (KPK) Province, at Tarari, district Muzaffarabad, in Azad Jammu \& Kashmir State and at Gunga, Surmai, Dhungei, district Khuzdar and at Duddar, district Lasbela, in Balochistan Province. An important lead-zinc mineralization belt has been discovered in ophiolite Thurst Belt in Khuzdar-Lasbela districts of Balochistan. Mineralization is confined to the upper part of the lower Jurassic Shirinab Formation. The mineralized area is spread over an area of $0.27 \mathrm{sq}$. km with a deposit length of $1.15 \mathrm{~km}$ and width $0.3 \mathrm{~km}$, respectively. The host rocks are mainly sedimentary carbonaceous mudstone, limestone and shale. The total reserves of Gunga, Surmai, Dhungei, and Duddar deposits have been estimated more than 28 million tonnes. However, average reserves of Duddar are estimated to be 15.5 million tonnes (Allen and Anwar, 1994; Jones and Sajjad, 1994; Zaigham, 1994; Ahmad, 1978).

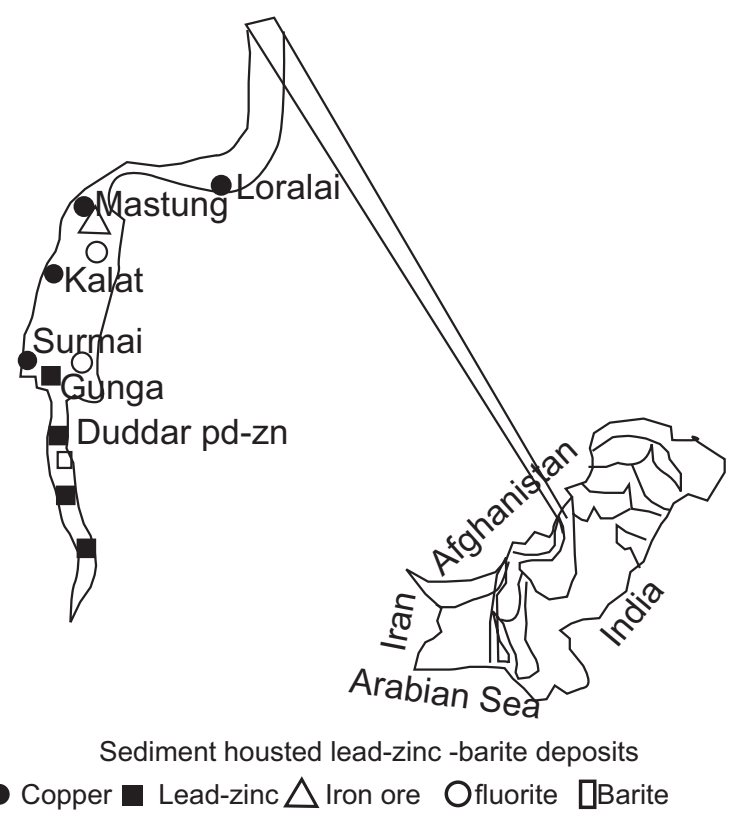

Map showing the location of lead-zinc ore deposit of Duddar, district Lasbela, Balochistan.

Sample preparation. A representative sample of ore was provided by Director, Pakistan Mineral Development Corporation (PMDC) for the beneficiation study. The bulk sample of ore as received consisted of lumps ranging in size from $100-150 \mathrm{~mm}$. About $100 \mathrm{~kg}$ of the ore was collected by coning-quartering of the bulk sample. The ore was subjected to size reduction by primary crushing using laboratory jaw crusher to a 
product size of 20-25 $\mathrm{mm}$ and by secondary crushing using roll crusher to a product size of 4-6 $\mathrm{mm}$. A head sample for chemical analysis and XRD was obtained by riffling of the crushed ore. It was ground to -200 mesh size with the help of disc pulverizer. The remaining ore was then split into approximately $1 \mathrm{~kg}$ samples for beneficiation study.

Chemical analysis. The gravimetric, volumetric and instrumental methods were applied to determine the main elements. Lead, zinc, barium, sulphur, silica and alumina were estimated by gravimetric methods. Iron was analyzed by oxidation-reduction titration. Calcium and magnesium were determined by complexometric titration while sodium and potassium by flame photometer (PFP7, Jenway Limited, England). The minor elements were determined by Atomic Absorption Spectrophotometer (Model: 8000, Hitachi, Japan). The chemical analysis of the representative sample is given in Table 1.

Mineralogy. The representative head sample was run on X-ray diffractometer (Model: D-5000, Siemens, Germany) equipped with $\mathrm{Cu} \mathrm{K} \alpha$ radiation with $\lambda=$ $0.15406 \mathrm{~nm}$ at $40 \mathrm{kV}$ and $30 \mathrm{~mA}$ to characterize the ore. The beam of monochromatic X-rays was allowed to fall on finely ground ore sample (-200 mesh size) at $25{ }^{\circ} \mathrm{C}$. X-ray diffraction was performed at scanning rate of 0.02 steps size per second in continuous mode. The scan angle $(2 \theta)$ was ranged from $20-80^{\circ}$ to obtain the main peaks of the minerals present in the ore. The spectrum obtained was matched with standard data to identify the various types of mineral phases. X-ray diffractrogram of the ore is shown in Fig.1 while the major and minor minerals identified in the ore are given Table 2 .

Degree of liberation: The mesh of liberation was measured by preparing grain mounts and studying under optical microscope (Nikon, Japan). The representative sample was crushed in roll crusher and ground in rod mill (Denver, USA) for $15 \mathrm{~min}$ and subjected to sieve shaker for size analysis. The fractions collected on different sieves were weighed. The grain mounts of various size fractions were prepared by placing a small amount of sample in one drop glycerin on a glass slide and covering with a cover slip. The number of liberated and locked mineral grains of galena and sphalerite in each sieve fraction were noted and the $\%$ age liberation was calculated. About 100 particles were counted for each slide. The order of liberation of galena and sphalerite minerals is shown in Table 3.
Flotation tests. The flotation tests were conducted in laboratory scale Denver flotation machine (Model: D12, USA) shown in Fig.2. The machine provides agitation to maintain thorough mixing and solid-liquid suspension. The rotation speed (rpm) of the agitator varied from 900 to 1200 by turning the knob at the top of the motor. An rpm tachometer is located at the top of the unit. Aeration is controlled using a needle valve. Measurements of $\mathrm{pH}$ were made by means of Hanna digital $\mathrm{pH}$ meter. The feed for the beneficiation study was prepared by wet grinding of rolls crusher product in rod mill (Denver, USA) at solid liquid ratio of 1:1. The grinding time was adjusted according to the required size of feed i.e. from $60 \%$ to $\sim 100 \%$ passing 200 mesh size. The ground ore $(1 \mathrm{~kg})$ was transferred to the stainless steel flotation cells of $4 \mathrm{~L}$ capacity and diluted with water to maintain the desired pulp density ranging from $15 \%$ to $35 \%$. Batch tests were performed utilizing various combination of flotation reagents i.e. collectors, frothers, regulators and modifiers on samples ground to different mesh sizes. After determining the optimum mesh of grind, the flotation tests were performed to optimize pulp density, agitation speed, pulp $\mathrm{pH}$, reagent addition, conditioning time and flotation time. All the experimental conditions along with type and amount of flotation reagents in various flotation tests have been mentioned below in the respective Figures.

In all tests a scavenging flotation was conducted and scavenger concentrate was mixed along with rougher concentrate. After having optimizing rougher flotation recovery, the test work was done to produce required grade concentrate and to define the flow sheet. The rougher concentrates were re-ground and two cleaning flotation operations were carried out with addition of flotation reagents. After preliminary tests to optimize flotation conditions, locked cycle tests were carried out with regrinding of rougher lead and zinc concentrates. The optimum parameters of galena and sphalerite flotation are shown in Tables 4 and 6, while the metallurgical balance of typical tests is given in Tables 5 and 7 , respectively. The chemical analysis of the final concentrates of lead and zinc is given in Table 8 .

\section{Results and Discussion}

Chemical composition. The chemical analysis of the representative sample given in Table 1 indicates the presence of total $3.12 \% \mathrm{wt} \mathrm{Pb}$ content and total $7.04 \%$ wt $\mathrm{Zn}$ content in the ore, respectively. The cut-off grade i.e. minimum content of both $\mathrm{Pb}$ and $\mathrm{Zn}$ required for 
Table 1. Chemical composition of the Duddar lead zinc Ore (composite sample)

\begin{tabular}{|c|c|c|c|}
\hline $\begin{array}{l}\text { Major } \\
\text { elements }\end{array}$ & $\begin{array}{l}(\mathrm{w} / \mathrm{w}) \\
(\%)\end{array}$ & $\begin{array}{l}\text { Minor } \\
\text { elements }\end{array}$ & $\begin{array}{l}\mathrm{ppm} \text { or } \\
\mathrm{mg} / \mathrm{kg}\end{array}$ \\
\hline $\mathrm{Pb}$ & 3.12 & $\mathrm{Cu}$ & 82 \\
\hline $\mathrm{Zn}$ & 7.04 & As & 40 \\
\hline $\mathrm{Fe}$ & 29.81 & $\mathrm{Ag}$ & 37 \\
\hline $\mathrm{S}$ & 38.20 & $\mathrm{Cd}$ & 35 \\
\hline $\mathrm{SiO}_{2}$ & 10.75 & $\mathrm{Cr}$ & 27 \\
\hline $\mathrm{Al}_{2} \mathrm{O}_{3}$ & 3.04 & $\mathrm{Hg}$ & 598 \\
\hline $\mathrm{CaO}$ & 2.23 & $\mathrm{Mn}$ & 170 \\
\hline $\mathrm{MgO}$ & 0.57 & $\mathrm{Sb}$ & 25 \\
\hline $\mathrm{BaO}$ & 1.64 & - & - \\
\hline $\mathrm{Na}_{2} \mathrm{O}$ & 1.28 & - & - \\
\hline $\mathrm{K}_{2} \mathrm{O}$ & 0.02 & - & - \\
\hline
\end{tabular}

economical processing is $0.5 \%$ if both of these metals are present in sulphide form (Singh, et al. 2009). As is evident from results, the percentage of lead and zinc is sufficient to exploit this polymetallic ore for commercial purposes. The other constituents present as main impurities include silica, alumina, iron oxide, barium oxide, calcium oxide, sodium oxide and potassium oxide. In order to reduce these impurities and consequently maximize the percentage of lead and zinc contents, it is necessary to adopt some beneficiation process for industrial utilization of this low grade ore.

Mineralogical composition. The X-ray diffraction analysis (Fig. 1) confirms the presence of considerable amount of galena $(\mathrm{PbS})$, sphalerite $(\mathrm{ZnS})$, pyrite $\left(\mathrm{FeS}_{2}\right.$ and quartz $\left(\mathrm{SiO}_{2}\right)$ minerals as major peaks of XRD correspond to standard values of these minerals. It was identified by JCP.CAT search \& match programmes of the X-ray Diffractometer that the minor peaks correspond to, marcasite $\left(\mathrm{FeS}_{2}\right)$, arsenopyrite (FeAsS), chalcopyrite $\left(\mathrm{CuFeS}_{2}\right)$, cinnabar $(\mathrm{HgS})$, barite $\left(\mathrm{BaSO}_{4}\right)$, calcite $\left(\mathrm{CaCO}_{3}\right)$, dolmite $\left[\mathrm{CaMg}\left(\mathrm{CO}_{3}\right)_{2}\right]$ and clay minerals. The chemical and mineralogical studies show that ore is predominantly made up of sphalerite and pyrite in association with subordinate amounts of galena, minor amounts of marcasite, chalcopyrite, traces of arsenopyrite and cinnabar. Quartz is the main gangue component. Mineralogical studies (Table 2) reveal that valuable minerals, both galena and sphalerite occur in sulphide form, so the froth flotation seems to be a more suitable process for its up-gradation as these minerals respond well to flotation. Moreover, separate minerals concentrate can be prepared by this technique.
Table 2. Mineralogical composition of Duddar lead zinc ore (composite sample)

\begin{tabular}{lllll}
\hline \hline Seq & 2Theta & D Value & Rel. I & Minerals identified \\
\hline 1 & 20.866 & 4.254 & 17.60 & Quartz \\
2 & 25.996 & 3.425 & 69.27 & Barite/galena/marcasite \\
3 & 26.791 & 3.326 & 31.79 & Sphalerite/quartz/cinnabar \\
4 & 28.824 & 3.096 & 100.00 & Sphalerite/calcite/barite/chalcopyrite \\
5 & 30.410 & 2.938 & 8.21 & Galena \\
6 & 33.322 & 2.687 & 36.35 & Arsenopyrite/pyrite/marcasite \\
7 & 36.081 & 2.4878 & 6.55 & Barite \\
8 & 37.343 & 2.407 & 16.43 & Barite/marcasite/arsenopyrite/pyrite \\
9 & 47.736 & 1.904 & 51.75 & Sphalerite//calcite \\
10 & 52.160 & 1.753 & 10.99 & Galena/marcasite/ quartz \\
11 & 54.451 & 1.684 & 12.50 & Sphalerite \\
12 & 56.540 & 1.627 & 33.22 & Pyrite/sphalerite \\
13 & 76.769 & 1.241 & 14.80 & Sphalerite \\
\hline \hline
\end{tabular}

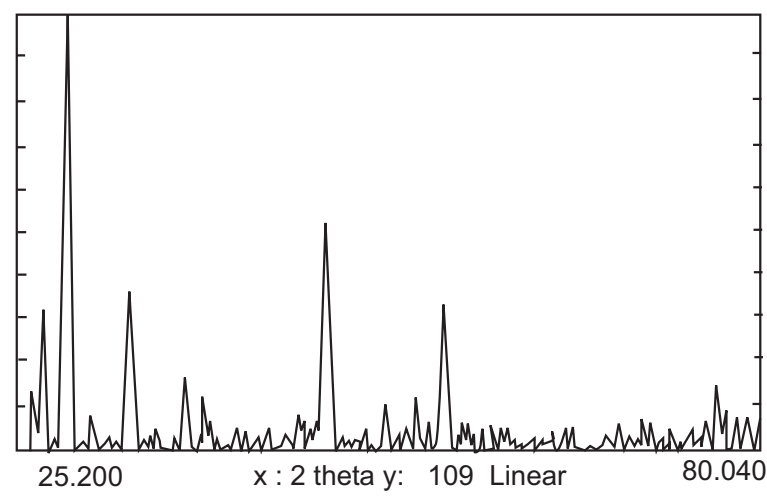

Fig. 1. XRD of lead-zinc ore of Duddar area, district Lasbela, Balochistan, Pakistan.

Mesh of liberation. The mesh of liberation results presented in Table 3 indicate that the fair liberation (72$76 \%$ ) of galena and sphalerite from associated gangues occurs around 100 mesh ASTM $(150 \mu \mathrm{m})$, however the mutual locking of galena with sphalerite and other sulphide minerals such as pyrite continues up to finer sizes (300 mesh ASTM). It is inferred from these results that optimum mesh of grind may lies in between 100 and 300 mesh size. It is therefore concluded that ore should be ground to 200 mesh size not only to liberate the sulphide minerals (galena, sphalerite and pyrite) from associated gangue minerals but also from one another. In practice, liberation is taken to the point where the economic yield of the process is maximized and particle size is seldom reduced to a point where $100 \%$ liberation is attained. The optimum mesh of grind is the particle size at which the most economic recovery can be obtained (Kazmi, et al. 2000). It is obvious from 
Table 3. Mesh of liberation of galena and sphalerite in Duddar lead zinc ore

\begin{tabular}{llll}
\hline \hline $\begin{array}{l}\text { Mesh no. } \\
(\text { ASTM })\end{array}$ & $\begin{array}{l}\text { Particle size } \\
(\mu \mathrm{m})\end{array}$ & \multicolumn{2}{c}{ Mineral liberation $(\%)$} \\
\cline { 3 - 4 } & 300 & 35.00 & Sphalerite \\
100 & 150 & 76.05 & Galena \\
150 & 106 & 85.36 & 72.25 \\
200 & 74 & 90.58 & 80.76 \\
250 & 63 & 95.05 & 91.36 \\
300 & 53 & 99.00 & 98.50 \\
\hline \hline
\end{tabular}

modal liberation analysis that the sphalerite grains show $84 \%$ liberation where as the galena particles show $90 \%$ liberation at 200 mesh size $(74 \mu \mathrm{m})$. Since, sufficient grinding i.e. more than 100 mesh size is necessary for liberation of minerals, therefore gravity concentration methods which operate at coarse size can not be applied for its economical processing. Fine grinding often generates slimes of valuable minerals which being small in size wash away with water in to tailings resulting poor recovery of concentrates. The froth flotation seems to be the most suitable technique to upgrade this kind of complex ore.

Selection of feed size. The ore is usually ground to liberate the valuable mineral grains from the associated gangue particles at the coarsest possible size. The separation of minerals at coarses size is always desirable because it not only saves the energy consumption during extra-grinding but also increase recovery due to decreased slimes losses (Singh et al., 2004). However, the coarse grinding is not practically viable to recover two or more valuable minerals into separate concentrates in case of complex mineral associations. Extremely fine intergrowth between galena and sphalerite minerals inhibits selective flotation separation and favours bulk flotation. Due to fine dissemination and interlocking of minerals, extensive fine grinding is often needed, which is energy intensive. In order to overcome these problems, it was decided to float the minerals in stages, first coarse and then fine. The purpose of coarse grinding is to maximize recovery by rendering most of valuable minerals floatable so that bulk of gangue can be discarded while in fine grinding the major consideration is the grade of concentrate. The increasing fine-grained nature and complexity of lead-zinc ores lead to the need for rougher concentrate to be ground extremely fine usually below 200 mesh size for economic recovery (Singh et al., 2004). As observed from Table 3, around $85 \%$ grains of both minerals are liberated at 200 mesh size.

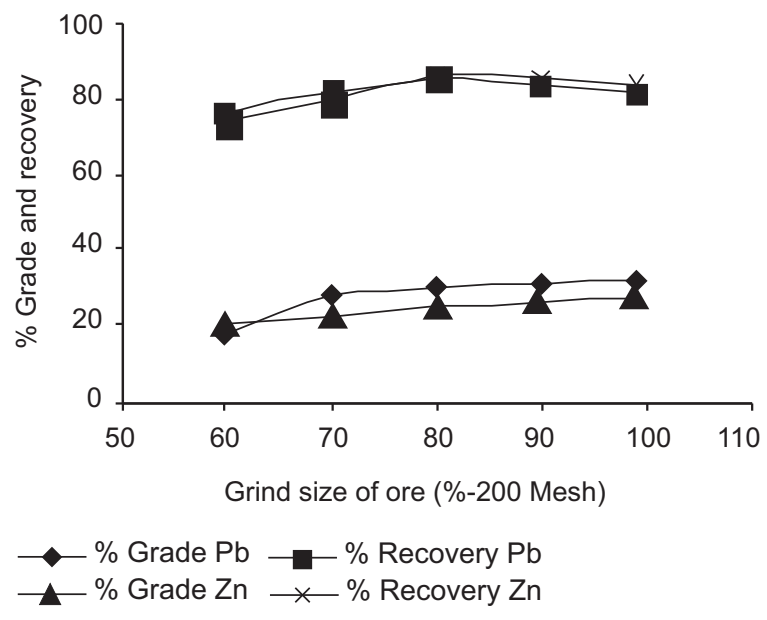

Fig. 2. Effect of ore grind size on grade \& recovery of rougher lead \& zinc concentrates.

Conditions. Pulp density; 25\%; Agitation speed, 1200 rpm; Pulp pH for galena, 8 \& for sphalerite,10: Gangue depressant (sodium silicate), $500 \mathrm{~g} /$ tonne; Pyrite depressant (sodium cyanide), $200 \mathrm{~g} /$ tonne; Sphalerite activator (copper sulphate), $500 \mathrm{~g} /$ tonne; Collector (PEX) for galena \& (PAX) for sphalerite, $100 \mathrm{~g} /$ tonne; Frother (polyglycol), $50 \mathrm{~g} /$ tonne; Conditioning time for galena,7 min. \& for sphalerite, $15 \mathrm{~min}$; Flotation time for galena, 15min \& sphalerite, 20 min.

Hence, the ore was ground in the range of 60 to $\sim 100 \%$ passing 200 mesh size to investigate the effect of this parameter. Results obtained at various grind sizes (Fig. 2) show that by decreasing the grain size from $60 \%$ to $80 \%$ passing 200 mesh size, the grade of lead concentrate was improved from $18.06 \%$ to $30.74 \%$ with maximum recovery of $85.12 \%$ and similarly the grade of zinc concentrate was improved from $20.04 \%$ to $25.38 \%$ with maximum recovery of $86.07 \%$ at feed size of $80 \%$ passing 200 mesh size. Further decrease in grain size slightly improved the grade but decreased the recovery probably due to production of slimes. Thus, this feed size showing the most economic recovery of galena and sphalerite at rougher stage was selected for onward study.

Effect of pulp density. The percentage of solid feed in the pulp is a key parameter which needs to be optimized. The optimum pulp density is of great importance as the effectiveness of reagents is a function of their concentration in solution. In general, the more dilute the pulp, the cleaner the separation. But, as a matter of economics, flotation separation is carried out in as dense pulp as possible consistent with good grade (Singh et al. 2004). The flotation trials were carried out at 
different values of pulp density (\% solids) within a range from $15-35 \%$ using flotation reagents and conditions optimized by mechanical cell flotation trials mentioned below Fig. 3. This figure shows that the increase in pulp density from $15 \%$ to $35 \%$ decreased the grade of lead and zinc concentrates slightly but increased the recovery. The maximum recovery of lead (85.97\%) and zinc (86.79\%) was achieved at 30\% solids. Beyond this value, the recovery decreased. It is due to fact that higher pulp density inhibits proper air dispersion and good bubble formation thereby adversely affecting the recovery (Crozier, 1992). At rougher stage, recovery is considered more important than the grade of concentrate and vice versa at cleaning stages Day (2002). Both galena and sphalerite could be best recovered at a pulp density of $30 \%$ solids at rougher stage. It was found that at cleaning and re-cleaning stages, better grade concentrates were obtained when pulp density was slightly lowered down to $20 \%$ and $15 \%$, respectively as shown in Table 4 and 6.

Effect of agitation. Another important parameter which affects the metallurgy of the galena and sphalerite concentrate is the agitation speed (aeration). A series of flotation tests was conducted in which agitation speed

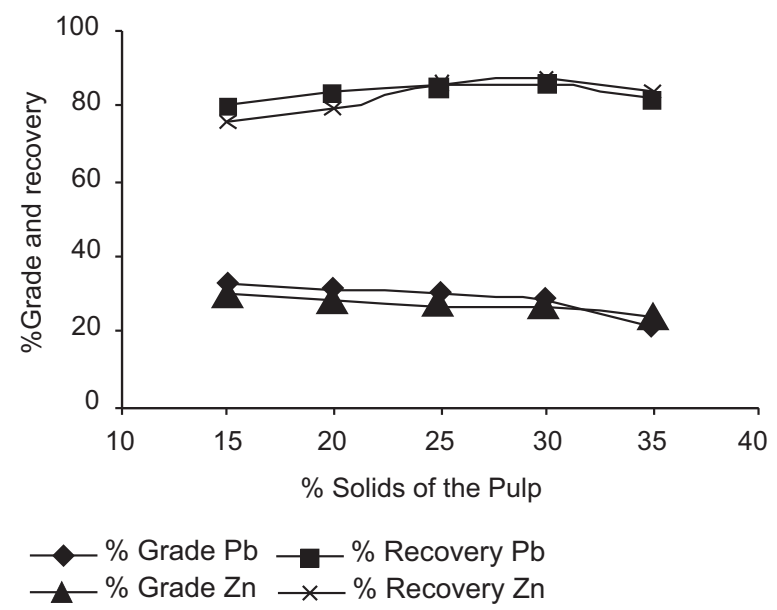

Fig. 3. Effect of pulp density on grade and recovery of rougher lead and zinc concentrates.

Conditions: Grind size, 80\%-200; Agitation speed, 1200 rpm; Pulp pH for galena, 8 \& sphalerite, 10; Gangue depressant (sodium silicate), $500 \mathrm{~g} /$ tonne; Pyrite depressant (sodium cyanide), $200 \mathrm{~g} /$ tonne; Sphalerite activator(copper sulphate), 500 g/tonne; Collector (PEX) for galena \& (PAX) for sphalerite, 80 g/tonne; Frother (polyglycol), $40 \mathrm{~g} /$ tonne; Conditioning time for galena, $7 \mathrm{~min}$. \& sphalerite, $15 \mathrm{~min}$; Flotation time for galena, $15 \mathrm{~min} \&$ sphalerite, $20 \mathrm{~min}$.
Table 4. Galena flotation parameters

\begin{tabular}{llll}
\hline \hline Parameters & \multicolumn{3}{c}{ Conditions } \\
\cline { 2 - 4 } & Roughing & Cleaning & Re-cleaning \\
\hline Grind size of ore & $80 \%-74 \mu$ & $98 \%-74 \mu$ & $98 \%-74 \mu$ \\
$\begin{array}{l}\text { Agitation speed } \\
\text { Pulp density }\end{array}$ & $1100 \mathrm{rpm}$ & $1000 \mathrm{rpm}$ & $900 \mathrm{rpm}$ \\
pH of pulp & $30 \%$ Solids & $20 \%$ Solids & $15 \%$ Solids \\
$\begin{array}{l}\text { Gangue depressant } \\
\text { (Sodium silicate) }\end{array}$ & $300 \mathrm{~g} / \mathrm{t}$ & $150 \mathrm{~g} / \mathrm{t}$ & $100 \mathrm{~g} / \mathrm{t}$ \\
$\begin{array}{l}\text { Pyrite depressant } \\
\text { (Sodium cyanide) }\end{array}$ & $150 \mathrm{~g} / \mathrm{t}$ & $70 \mathrm{~g} / \mathrm{t}$ & $50 \mathrm{~g} / \mathrm{t}$ \\
$\begin{array}{l}\text { Sphalerite depressant } \\
\text { (Zinc sulphate) }\end{array}$ & $\mathrm{Nil}$ & $200 \mathrm{~g} / \mathrm{t}$ & $100 \mathrm{~g} / \mathrm{t}$ \\
$\begin{array}{l}\text { Collector (Potassium } \\
\text { ethyl xanthate) }\end{array}$ & $70 \mathrm{~g} / \mathrm{t}$ & $50 \mathrm{~g} / \mathrm{t}$ & $\mathrm{Nil}$ \\
$\begin{array}{l}\text { Frother } \\
\text { (Polypropylene glycol) }\end{array}$ & $30 \mathrm{~g} / \mathrm{t}$ & $20 \mathrm{~g} / \mathrm{t}$ & $\mathrm{Nil}$ \\
$\begin{array}{l}\text { Conditioning time } \\
\text { Flotation time }\end{array}$ & $5 \mathrm{~min}$ & $5 \mathrm{~min}$ & $5 \mathrm{~min}$ \\
\hline \hline
\end{tabular}

Table 5. Metallurgical balance for galena flotation

\begin{tabular}{|c|c|c|c|c|c|}
\hline \multirow[t]{2}{*}{ Products of flotation } & \multirow{2}{*}{$\begin{array}{c}\text { Weight } \\
(\%)\end{array}$} & \multicolumn{2}{|c|}{ Assay \% } & \multicolumn{2}{|c|}{ Distribution $\%$} \\
\hline & & $\overline{\mathrm{Pb}}$ & $\mathrm{Zn}$ & $\mathrm{Pb}$ & $\mathrm{Zn}$ \\
\hline Lead re-cleaner Concentrate & 3.77 & 65.24 & 1.08 & 81.32 & 20.58 \\
\hline Lead re-cleaner Tailings & 0.70 & 12.21 & 9.35 & 2.74 & 0.93 \\
\hline Lead cleaner concentrate & 4.47 & 58.62 & 2.37 & 84.06 & 61.51 \\
\hline Lead cleaner tailings & 3.50 & 5.63 & 6.94 & 6.32 & 3.45 \\
\hline Lead rougher concentrate & 7.97 & 35.40 & 4.38 & 90.38 & 3.96 \\
\hline Zinc rougher concentrate & 22.51 & 0.77 & 28.71 & 5.60 & 91.78 \\
\hline Bulk rougher tailings & 69.52 & 0.18 & 0.33 & 4.02 & 3.26 \\
\hline Head sample & 100 & 3.12 & 7.04 & 100.0 & 100.0 \\
\hline
\end{tabular}

of pulp varied from 800 to $1200 \mathrm{rpm}$. Figure 4 illustrates the results regarding the effect of agitation speed on grade and recovery of rougher concentrates. It was found that higher agitation speed of around $1100 \mathrm{rpm}$ gave better metallurgical performance (i.e. grade and recovery) at rougher stage. The lead concentrate assaying $31.12 \% \mathrm{~Pb}$ with \% recovery of $86.58 \%$ and zinc concentrate assaying $25.46 \% \mathrm{Zn}$ with recovery of $87.36 \%$ was achieved. The flotation process uses hydrophilic or hydrophobic chemical reagents with aeration to separate suspended particles (Bulatovic, 2007). A higher agitation helps to float the collectorcoated mineral grains (hydrophobic) containing liberated as well as some partially exposed grains by attaching them on rising air bubbles and thus increases the recovery. At lower agitation, no doubt, the grade is improved but the recovery decreases slightly due to the fact that the middling particles being partly hydrophilic remain in pulp. It is desirable to have a higher recovery at rougher stage rather than grade so this value was selected (Li and Zhang, 2012). But at cleaning and 


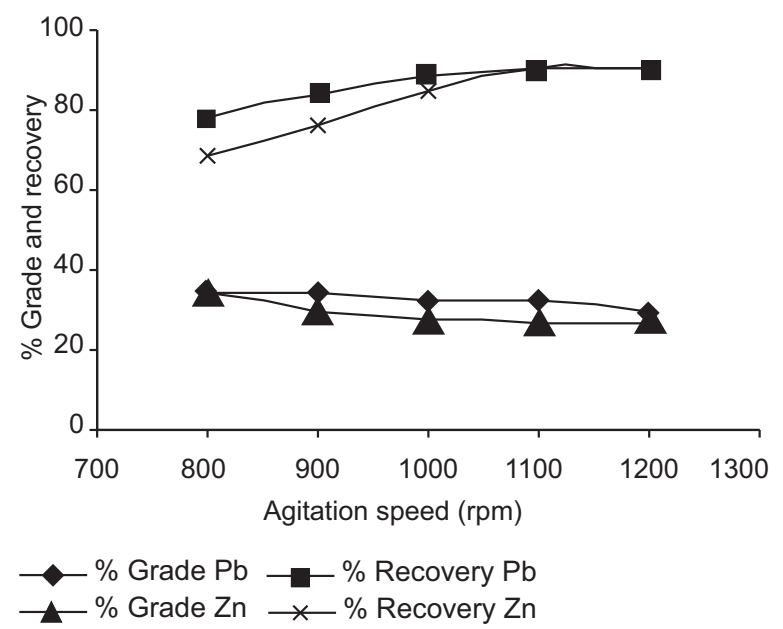

Fig. 4. Effect of agitation speed on grade and recovery of rougher lead and zinc concentrates.

Conditions. Grind size, 80\%-200 ; Pulp density, 30\%; Pulp $\mathrm{pH}$ for galena, 8 \& for sphalerite, 10; Gangue depressant (sodium silicate), $500 \mathrm{~g} /$ tonne; Pyrite depressant (sodium cyanide), $200 \mathrm{~g} /$ tonne; Sphalerite activator(copper sulphate), $500 \mathrm{~g} /$ tonne; Collector (PEX) for galena \& (PAX) for sphalerite, 100 g/tonne; Frother (polyglycol), 50 g/tonne; Conditioning time for galena, $7 \mathrm{~min}$. \& sphalerite, $15 \mathrm{~min}$; Flotation time for galena, $15 \mathrm{~min} \&$ sphalerite, $20 \mathrm{~min}$.

re-cleaning stages, a lower agitation speed of $1000 \mathrm{rpm}$ and $900 \mathrm{rpm}$ was found suitable to produce cleaner concentrates of greater purity with reasonable recovery

Table 6. Sphalerite floatation parameters

\begin{tabular}{llll}
\hline \hline Parameters & \multicolumn{3}{c}{ Conditions } \\
\cline { 2 - 4 } & Roughing & Cleaning & $\begin{array}{l}\text { Re- } \\
\text { Cleaning }\end{array}$ \\
\hline Grain size & $80 \%-74 \mu \mathrm{m}$ & $98 \%-74 \mu \mathrm{m}$ & $\begin{array}{l}98 \%- \\
74 \mu \mathrm{m}\end{array}$ \\
$\begin{array}{l}\text { Agitation speed } \\
\text { Pulp density }\end{array}$ & $1100 \mathrm{rpm}$ & $1000 \mathrm{rpm}$ & $\begin{array}{l}900 \mathrm{rpm} \\
15 \%\end{array}$ \\
$\begin{array}{l}\text { pH of pulp } \\
\begin{array}{l}\text { Gangue depressant } \\
\text { (sodium silicate) }\end{array}\end{array}$ & $30 \% \mathrm{solids}$ & $20 \% \mathrm{solids}$ & $\begin{array}{l}15 \% \\
\text { solids }\end{array}$ \\
$\begin{array}{l}\text { Pyrite depressant } \\
\text { (sodium cyanide) }\end{array}$ & $150 \mathrm{~g} / \mathrm{t}$ & $70 \mathrm{~g} / \mathrm{t}$ & $50 \mathrm{~g} / \mathrm{t}$ \\
$\begin{array}{l}\text { Sphalerite activator } \\
\text { (copper sulphate) }\end{array}$ & $400 \mathrm{~g} / \mathrm{t}$ & $200 \mathrm{~g} / \mathrm{t}$ & $\mathrm{Nil}$ \\
$\begin{array}{l}\text { Galena depressant } \\
\text { (sodium chromate) }\end{array}$ & $\mathrm{Nil}$ & $40 \mathrm{~g} / \mathrm{t}$ & $20 \mathrm{~g} / \mathrm{t}$ \\
$\begin{array}{l}\text { Collector } \\
\text { (potassium amylxanthate) }\end{array}$ & $80 \mathrm{~g} / \mathrm{t}$ & $60 \mathrm{~g} / \mathrm{t}$ & $\mathrm{Nil}$ \\
$\begin{array}{l}\text { Frother } \\
\text { (polypropylene glycol) }\end{array}$ & $40 \mathrm{~g} / \mathrm{t}$ & $20 \mathrm{~g} / \mathrm{t}$ & $\mathrm{Nil}$ \\
$\begin{array}{l}\text { Conditioning time } \\
\text { Flotation time }\end{array}$ & $15 \mathrm{~min}$ & $15 \mathrm{~min}$ & $15 \mathrm{~min}$ \\
\hline \hline & $20 \mathrm{~min}$ & $20 \mathrm{~min}$ & $20 \mathrm{~min}$ \\
\hline
\end{tabular}

i.e. more than $80 \%$ as shown in Table 4 and 6 . This effect is due to the fact that on re-grinding, the particle size is further reduced which favours lower rpm.

Effect of pH. The control of slurry $\mathrm{pH}$ is a very critical parameter in many selective flotation circuits. In order to determine the appropriate $\mathrm{pH}$ value for flotation, a number of tests were carried out. According to selected experimental conditions, galena was recovered before sphalerite. Galena flotation was performed in a slightly alkaline media. Soda ash was used to adjust the pulp $\mathrm{pH}$ during lead flotation instead of cheap lime. Although lime acts as a strong depressant for pyrite present in ore, it can also depress galena to some extent (Jain, 2001). Therefore, soda ash was used in present study to get higher recovery. It also acts as dispersant for slimes (Silvestre et al., 2009). The flotation trials were conducted in alkaline $\mathrm{pH}$ ranging from 8 to 11 using potassium ethyl xanthate (PEX) as collector. The results are shown in the Fig. 5. The grade and recovery of lead concentrate is showing increasing trend up to $\mathrm{pH}$ value of 9 , beyond which there is no significant improvement. The best grade lead concentrate containing $32.24 \% \mathrm{~Pb}$ with $86.93 \%$ recovery was obtained. Hence, for further trials, the $\mathrm{pH}$ value of 9 was kept fixed. It is evident

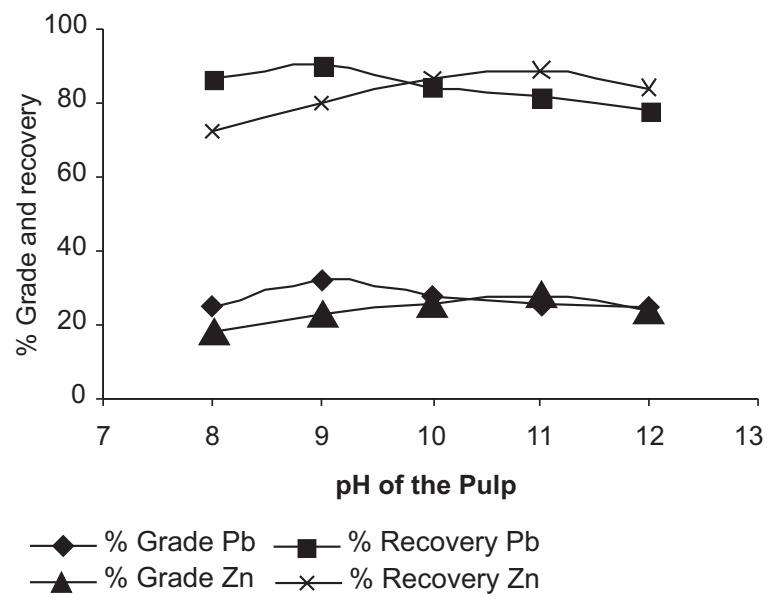

Fig. 5. Effect of $\mathrm{pH}$ of the pulp on grade and recovery of rougher lead and zinc concentrates.

Conditions. Grind size, 80\%-200 ; Pulp density, 30\%; Agitation speed 1100 rpm; Gangue depressant (sodium silicate), 500 g/tonne; Pyrite depressant (sodium cyanide), $200 \mathrm{~g} /$ tonne; Sphalerite activator(copper sulphate), $500 \mathrm{~g} /$ tonne; Collector (PEX) for galena \& (PAX) for sphalerite, $100 \mathrm{~g} /$ tonne; Frother (polyglycol), $50 \mathrm{~g} /$ tonne; Conditioning time for galena, $7 \mathrm{~min}$. \& for sphalerite, $15 \mathrm{~min}$; Flotation time for galena, $15 \mathrm{~min}$ \& sphalerite, $20 \mathrm{~min}$. 
from the result that pulp alkalinity plays a very crucial role in flotation of sulphide minerals as selectivity in separation is dependent on delicate balance between reagents concentration and $\mathrm{pH}$. Even a small variation in $\mathrm{pH}$ affects significantly on the assay and recovery of concentrate where the effect is on the maximum stability of metal-xanthate complex.

Rejected sphalerite during galena flotation was then recovered in a second flotation step after activation with copper ions. When sodium ethyl xanthate, a more aggressive collector was tried, the pyrite was floated as well in addition to sphalerite. Thus, less powerful but more selective flotation collector such as potassium amyl xanthate (PAX) was used for sphalerite flotation. It was observed that not only sphalerite was readily floated after activation with copper sulphate but also some pyrite was activated at this step. In order to prevent pyrite activation with copper sulphate during conditioning step and in turn enhancing the rejection of pyrite to the sphalerite flotation tailings, sphalerite flotation was practiced in strongly alkaline media (Milena, 2011). Lime was used to raise $\mathrm{pH}$ as well as for iron sulphide depression. Pyrite did not float in strongly alkaline $\mathrm{pH}$ media i.e. $\mathrm{pH}$ more than 10.5 because it forms colloidal hydrated iron oxides, rendering the surface hydrophilic and hindering interaction with the collector (Wills and Napier-Munn, 2006). Lime was applied during sphalerite flotation to control $\mathrm{pH}$ range from 9 to 12 . Pyrite was not floated in this study and was delivered to the bulk flotation tailings. The results are depicted in the Fig. 5. Results collected at different $\mathrm{pH}$ values show that the best grade zinc concentrate possessing $26.54 \%$ zinc content with maximum recovery of $88.76 \%$ was observed at $\mathrm{pH}$ value of 11 . Hence, it was considered as optimum $\mathrm{pH}$ value and selected for further trials.

Effect of pyrite depressant. Sodium cyanide was used as a depressant for pyrite mineral during galena flotation. It was found that galena float readily in the presence of cyanide. It activates probably due to its cleaning action on surfaces of galena particles (Milena, 2011). In fact, cyanide was utilized to affect more selective flotation of galena in the presence of zinc and iron sulphide minerals. It increased the selectivity of flotation by rendering pyrite hydrophilic and thus preventing its flotation (Gaudin, 2001). A number of trials were conducted using various concentrations of sodium cyanide to prevent the flotation of pyrite. The results obtained are represented in Fig 6. An optimum value of $150 \mathrm{~g} /$ ton of sodium cyanide yields the best

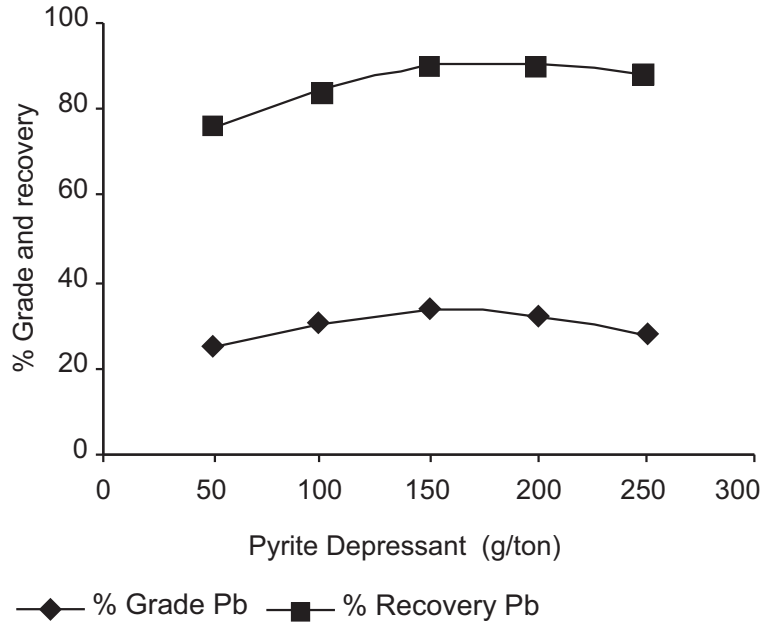

Fig. 6. Effect of pyrite depressant on grade and recovery of rougher lead and zinc concentrates.

Conditions. Grind size, 80\%-200 ; Pulp density, 30\%; Agitation speed, 1100 rpm; Pulp pH for galena, 9; Gangue depressant (sodium silicate), $300 \mathrm{~g} /$ tonne; Collector (PEX) for galena, 100 g/tonne; Frother (polyglycol), $50 \mathrm{~g} /$ tonne; Conditioning time for galena, $7 \mathrm{~min}$, Flotation time for galena, $15 \mathrm{~min}$.

concentrate grade $(33.07 \% \mathrm{~Pb})$ with optimum recovery $(88.20 \%)$ and kept constant for further trials. At the cleaning stages, addition of slight amount also produced better results as the remaining pyrite particles were rejected in cleaning flotation. Zinc sulphate was added in small quantity (100-200 g/t) to make the sphalerite non-floatable in lead cleaning flotation. In lead flotation, act as an inhibitor of sphalerite flotation under alkaline pulp condition by deactivation. Similarly, sodium chromate (20-40 g/t) was applied to depress galena in zinc cleaning flotation. Sodium chromate inhibits the flotation of galena by the formation of stable and nonreactive lead chromate on the surface of galena mineral particles (Jain, 2001).

Effect of sphalerite activator. The flotation of galena was followed by sphalerite flotation experiments. It has been found practically that sphalerite mineral rarely floats well with xanthate because of relatively high solubility of zinc-xanthate complex. However, the mineral readily floats after activation with copper sulphate. In fact, the copper ions replace zinc atoms on the sphalerite surface forming a pseudo-copper mineral surface. The copper sulphide so formed at mineral surface is more stable than zinc sulphide in alkaline $\mathrm{pH}$ and is collected using copper flotation type collector. It reacts readily with xanthate to form insoluble copper- 


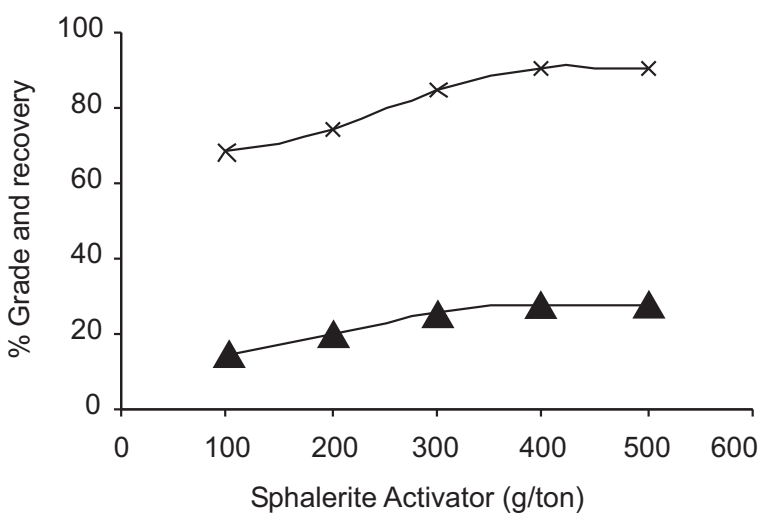

$\leftarrow \%$ Grade $\mathrm{Zn} \rightarrow \%$ Recovery $\mathrm{Zn}$

Fig. 7. Effect of sphalerite activator on grade and recovery of rougher lead and zinc concentrates.

Conditions. Grind size, 80\%-200 ; Pulp density, 30\%; Agitation speed, 1100 rpm; Pulp pH for sphalerite, 11; Gangue depressant (sodium silicate), $300 \mathrm{~g} /$ tonne; Collector (PAX) for sphalerite, $100 \mathrm{~g} /$ tonne; Frother (polyglycol), $50 \mathrm{~g} /$ tonne; Conditioning time for sphalerite, $15 \mathrm{~min}$. Flotation time, $20 \mathrm{~min}$.

xanthate complex which is hydrophobic in nature and can easily attach with air bubbles (Wills and NapierMunn, 2006). After performing a series of tests using different concentrations of activator, it was found that $400 \mathrm{~g} / \mathrm{t}$ copper sulphate gave the optimum grade $(27.68 \%$ $\mathrm{Zn})$ and recovery $(89.26 \%)$ while keeping all other parameters constant (Fig. 7). Hidayet, et al. (2002) performed a study on collectorless flotation of lead and zinc sulphide present in the Derekoy ore in the presence of sodium sulphide but in that case recovery was poor.

Effect of gangue depressants. The common gangue minerals include quartz, calcite, barite and clays as found from mineralogical study. Various types of depressants such as guar gum, quebracho, gelatin, tannin, sodium hexametaphosphate, sodium polyacrylate and sodium silicate were used in a few preliminary flotation tests to depress these minerals (Kashani and Rashchi, 2008). It was observed that sodium silicate was the most effective depressant. Hence, next set of trials were performed using various concentrations of sodium silicate as a regulator to depress these minerals in the pulp by rendering them hydrophilic (Rao, 2004). The results obtained using different quantities of depressant are plotted in the Fig. 8. With an increase in amount of the depressant (sodium silicate), the grade and recovery of the both concentrates were improved and the best

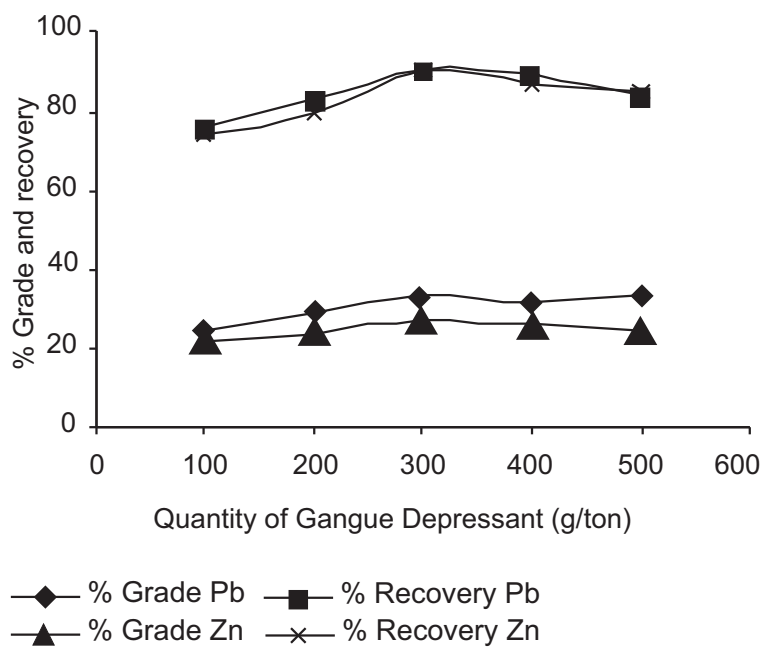

Fig. 8. Effect of gangue depressant on grade and recovery of rougher lead and zinc concentrates.

Conditions. Grind size, 80\%-200 ; Pulp density, 30\%; Agitation speed, 1100 rpm; Pulp pH for galena, 9 \& sphalerite, 11; Pyrite depressant (sodium cyanide), $200 \mathrm{~g} /$ tonne; Sphalerite activator (copper sulphate), $500 \mathrm{~g} /$ tonne; Collector (PEX) for galena, $70 \mathrm{~g} /$ tonne \& (PAX) for sphalerite, $80 \mathrm{~g} /$ tonne; Frother (polyglycol), $50 \mathrm{~g} /$ tonne; conditioning time for galena, $7 \mathrm{~min}$; \& for sphalerite, 15 minne; flotation time for galena, 15 min \& sphalerite, 20 min.

grade lead concentrate $(33.74 \% \mathrm{~Pb})$ and zinc concentrate $(27.95 \% \mathrm{~Pb})$ was obtained at a depressant concentration of $300 \mathrm{~g} /$ tonne. Although the grade improved a little beyond that point, the recovery decreased. Hence, for further trials the depressant concentration of $300 \mathrm{~g} /$ tonne was kept fixed. It can be explained that sodium silicate efficiently depresses the gangue minerals by using moderate amount of it as a gangue depressant and slime dispersant but excessive amount decreases the recovery due to an over coating of some middling particles (Silvestre, et al. 2009). At cleaning and recleaning stages lesser amount of sodium silicate gave the better result due to less amount of gangue materials present as shown in Table 4 and 6, respectively.

Effect of collectors. Xanthates (dithiocarbonate) were used as collector for flotation of galena and sphalerite minerals instead of less powerful Aerofloats (dithiophosphates). They are very selective for refractory sulphide minerals and perform well in alkaline circuits (Bulatovic, 2007). They adsorb on minerals surfaces resulting insoluble metal xanthate complexes which are strongly hydrophobic. A number of xanthate collectors i.e. potassium ethyl xanthate (PEX), potassium isopropyl 


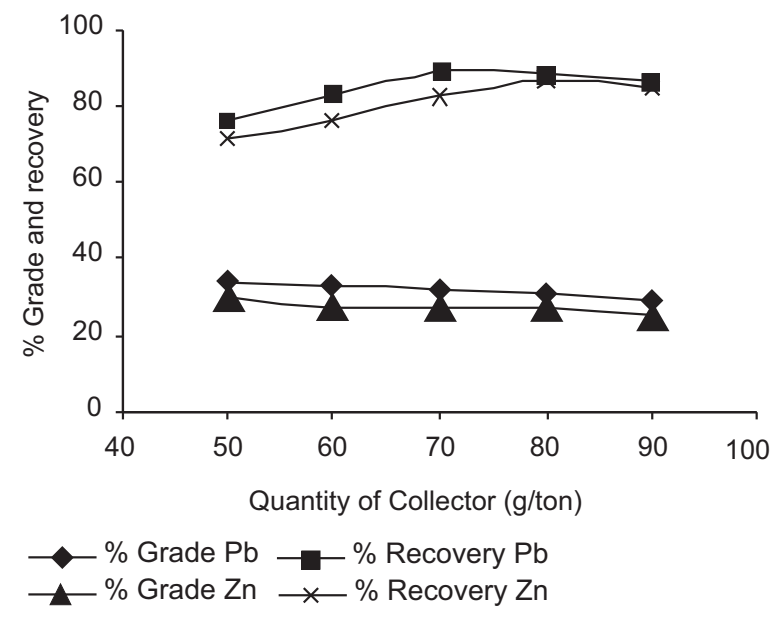

Fig. 9. Effect of collectors on grade and recovery of the rougher lead and zinc concentrates.

Conditions. Grind size, 80\%-200 ; Pulp density, 30\%; Agitation speed, 1100 rpm; Pulp pH for galena, 9 \& sphalerite: 11; Gangue depressant (sodium silicate), $300 \mathrm{~g} /$ tonne; Pyrite depressant (sodium cyanide), $150 \mathrm{~g} /$ tonne; Sphalerite activator (copper sulphate),400 g/tonne; Frother (polyglycol), $50 \mathrm{~g} /$ tonne; Conditioning time for galena, $7 \mathrm{~min}$; \& sphalerite, $15 \mathrm{~min}$; Flotation time for galena, $15 \mathrm{~min} \&$ sphalerite, $20 \mathrm{~min}$.

xanthate (PIPX), potassium butyl xanthate (PBX) and potassium amyl xanthate (PAX) were tested for the flotation of galena and sphalerite in the preliminary trials. It was observed that PEX, a lower molecular weight xanthate, produced comparatively higher result in term of grade for galena and PAX, a higher molecular weight xanthate for sphalerite. Hence, few flotation trials were conducted using varying concentrations of PEX. The results of these trials are indicated in the Fig. 9. Lead concentrate $(\mathrm{Pb} 34.10 \%)$ with maximum recovery of $89.36 \%$ was collected at $70 \mathrm{~g} /$ tonne dosage of PEX. Hence, for further trials, this amount was kept fixed. The additions of PAX collector up to $80 \mathrm{~g} /$ tonne produced maximum separation efficiency $(90.08 \%)$ in case of zinc concentrate ( $\mathrm{Zn} 28.19 \%$ ). It is clear from the figure that excessive amount of collector, greater than starvation level, adversely affect the grade and recovery of respective concentrates. It is due to over oiling effect of the collector that reduces the selectivity by the development of multi-layers on the mineral particles (Wills and Napier-Munn, 2006). It was noted that at cleaning stage, an additional quantity of collector was required for newly liberated mineral particles produced by re-grinding of rougher concentrate. But at re-cleaning stage, addition of collector dosage did not affect the metallurgy. It was supposed that mineral particles were already coated and required no further addition of collector.

Effect of frothers. The amount of frother added to the flotation system is an important variable because the frother increases the rate of flotation significantly. It adsorbs on the air-water interface to reduce the surface tension thus stabilizing the froth (Khoshdast and Sam, 2011; Melo and Laskowski, 2006). Initially, a few flotation trials were conducted to study the effect of frother addition on the recovery of lead and zinc minerals using various types of frother such as ethyl alcohol, polypropylene glycol, cresylic acid, methyl isobutyl carbinol (MIBC) and pine oil (Tan, et al. 2005). Ethyl alcohol, being a low molecular weight frother, although showed higher selectivity in sphalerite flotation but recovery was low. On the other hand, galena floated well by MIBC, a weaker type frother but due to high density of galena it did not produce better metallurgical response. It was observed that polypropylene glycol (Dowfroth-250), a stronger frother, provides higher recoveries and better performance. It produced more persistent and viscous froth of galena and sphalerite. The results obtained using different quantities of polypropylene glycol (Polyglycol) frother are indicated in the Fig. 10. It is clearly seen from the figure that

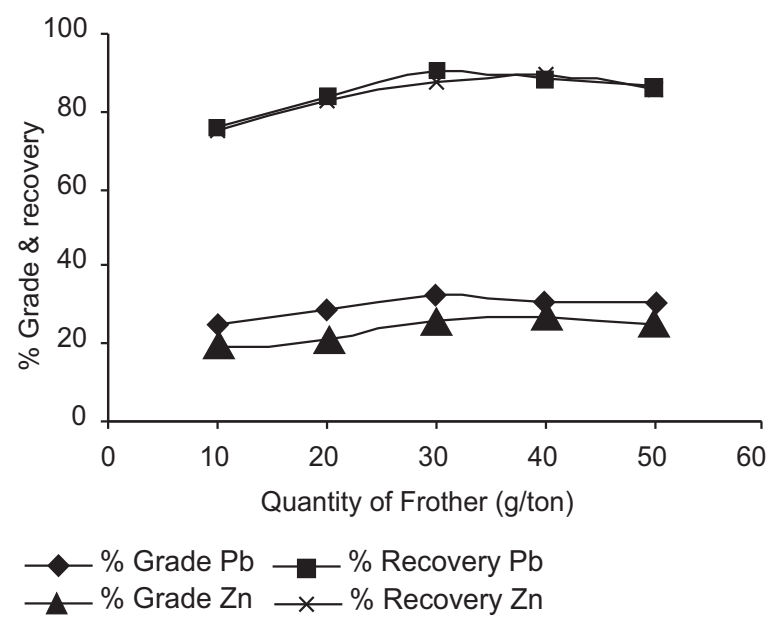

Fig. 10. Effect of frother on grade and recovery of the rougher lead and zinc concentrates.

Conditions. Grind size, 80\%-200 ; Pulp density, 30\%; Agitation speed, 1100 rpm; Pulp pH for galena, 9 \& sphalerite, 11; Gangue depressant (sodium silicate), 300 g/tonne; Pyrite depressant (sodium cyanide), $150 \mathrm{~g} /$ tonne; Sphalerite activator (copper sulphate), $400 \mathrm{~g} /$ tonne; Collector (PEX) for galena, $70 \mathrm{~g} /$ tonne \& (PAX) for sphalerite, $80 \mathrm{~g} /$ tonne; Conditioning time for galena, $7 \mathrm{~min}$ \& for sphalerite, $15 \mathrm{~min}$; Flotation time for galena, $15 \mathrm{~min} \&$ sphalerite, $20 \mathrm{~min}$. 
grade and recovery of lead concentrate increases from $18.06 \%$ to $34.27 \%$ and recovery from $85.27 \%$ to $90.03 \%$ and similarly the grade of zinc concentrate from $22.24 \%$ to $28.38 \%$ and recovery from $87.52 \%$ to $91.14 \%$ continuously up to a frother dosage of $30 \mathrm{~g} /$ tonne and for zinc concentrate up to $40 \mathrm{~g}$ /tonne beyond which the increase is very marginal. Hence, for further flotation trials, the frother dosage was kept fixed. It was observed that at low addition rates, less than optimum point, froth is unstable and recovery of minerals is slow. While on the other hand, increasing frother addition rate has a marked effect on the flotation rate of valuable minerals, increasing the weight and reducing the grade of concentrate produced. It is worth mentioning that stage addition of frother also helped to control the volume of froth.

Effect of conditioning time. The conditioning time as well as point of flotation reagents addition has a large influence on grade and recovery of the rougher concentrates. Conditioning prior to flotation is a standard practice and is important in decreasing the flotation time. Appropriate conditioning allows the mineral grain surfaces to react with the reagents in the pulp. The ideal

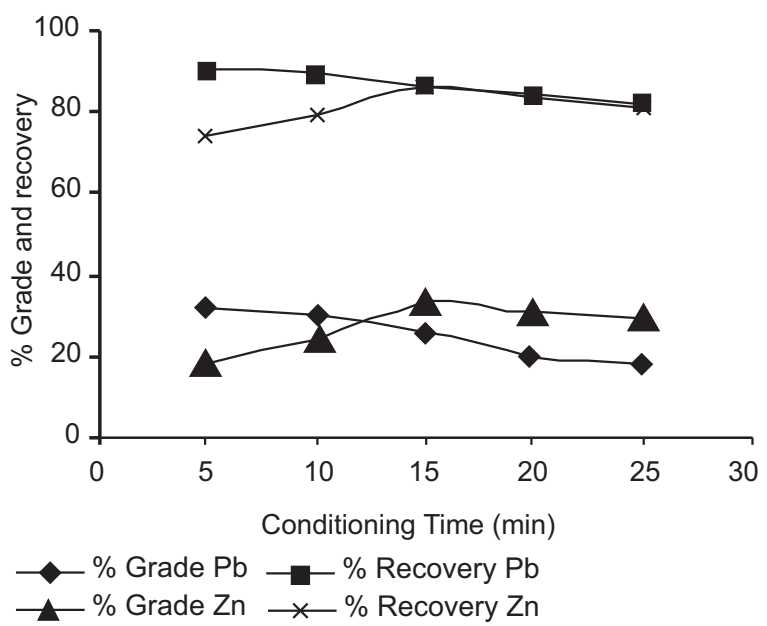

Fig. 11. Effect of conditioning time on grade and recovery of rougher lead and zinc concentrates.

Conditions. Grind size, $80 \%-200$; Pulp density, 30\%; Agitation speed, 1100 rpm; Pulp pH for galena, 9 \& sphalerite, 11; Gangue depressant (sodium silicate), $300 \mathrm{~g} /$ tonne; Pyrite depressant (sodium cyanide), $150 \mathrm{~g} /$ tonne; Sphalerite activator (copper sulphate), $400 \mathrm{~g} /$ tonne; Collector (PEX) for galena, 70g/tonne \& (PAX) for sphalerite, $80 \mathrm{~g} /$ tonne; Frother (polyglycol) for galena, $30 \mathrm{~g} /$ tonne \& sphalerite, $40 \mathrm{~g} /$ tonne; Flotation time for galena,15min \& sphalerite, $20 \mathrm{~min}$. conditioning converts the minerals in readily floatable form (Wills and Napier-Munn, 2006). Results obtained for different conditioning time i.e. 5, 10, 15, 20 and 25 min are shown in Fig. 11. Grade and recovery improves with increase in conditioning time of the pulp. A conditioning time of $5 \mathrm{~min}$ for galena and $15 \mathrm{~min}$ for sphalerite was found sufficient for the contact with the mineral particles for optimum recovery and grade. The lead concentrate $(34.82 \% \mathrm{~Pb})$ with recovery rate of $90.17 \%$ and zinc concentrate $28.36 \% \mathrm{Zn}$ with recovery rate of $91.56 \%$ was prepared. It seems that a prolonged conditioning time has a deleterious effect on flotation rate. It destabilizes the collector-mineral complex resulting in lower flotation grade and recovery.

Effect of flotation time. Flotation tests were carried out at different time intervals to achieve optimum flotation reagent dosages and conditions. The data collected is expressed graphically in Fig. 12. The rate of flotation increases gradually with increase in time intervals and best results in term of grade and recovery are achieved after $15 \mathrm{~min}$ for galena and $20 \mathrm{~min}$ for sphalerite flotation. The lead concentrate possessing $35.40 \% \mathrm{~Pb}$ with $90.38 \%$ recovery and zinc concentrate

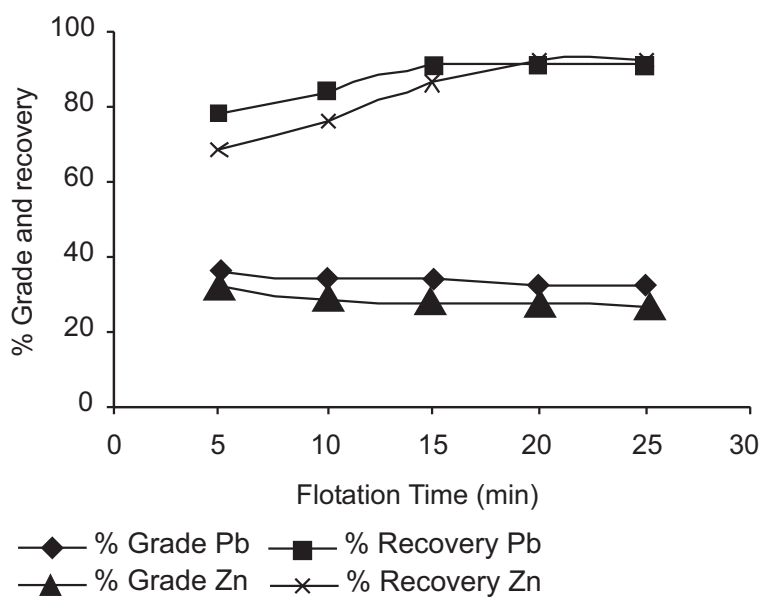

Fig. 12. Effect of flotation time on grade and recovery of rougher lead and zinc concentrates.

Conditions. Grind size: $80 \%-200$ \#, Pulp density: 30\%, Agitation speed: $1100 \mathrm{rpm}$, Pulp pH for galena: 9 \& sphalerite: 11, Gangue depressant (sodium silicate): $300 \mathrm{~g} /$ tonne, Pyrite depressant (sodium cyanide): $150 \mathrm{~g} /$ tonne, Sphalerite activator (copper sulphate): $400 \mathrm{~g} /$ tonne, Collector (PEX) for galena: 70g/tonne \& (PAX) for sphalerite: 80 g/tonne, Frother (polyglycol) for galena:30 g/tonne \& for sphalerite: $40 \mathrm{~g} /$ tonne, Conditioning time for galena: $5 \mathrm{~min}$. \& for sphalerite: $15 \mathrm{~min}$. Flotation time: varied 
having $28.71 \% \mathrm{Zn}$ with $91.78 \%$ recovery was attained. Hence, flotation for 15 and $20 \mathrm{~min}$ is enough to completely barren the froth in cases of both concentrates and further time has no pronounced effect on the resulting metallurgy. These were considered as optimum flotation time for both flotations.

Effect of cleanings. The rougher flotation tests were followed by scavenging flotation and scavenger concentrate was mixed along with rougher concentrate to enhance and promote the rougher flotation recovery by minimizing the losses to the rougher tailings being discarded. The rougher concentrates were re-ground and two cleaning flotation operations were carried out with addition of flotation reagents. Several numbers of cleaning tests were performed to improve the concentrate grade. Flotation reagents were added as additional dosage during each cleaning flotation. Regrinding of the middlings products consisting mainly of unliberated minerals, both the scavenger product and the cleaner tailings, is common practice in most flotation plants $(\mathrm{Li}$ and Zhang, 2012). The rougher concentrates obtained and cleaning tailings were re-ground for further liberation of fine mineral grains and cleaned by two cleaning operations to get the final concentrates. The tailings of cleaning stages were circulated, according to its grade, to improve the overall recovery. Table 4 represent the optimum reagent consumption for lead flotation as 70 $\mathrm{g} / \mathrm{t}$ potassium ethyl xanthate, $300 \mathrm{~g} / \mathrm{t}$ sodium silicate, $150 \mathrm{~g} / \mathrm{t}$ sodium cyanide, $30 \mathrm{~g} / \mathrm{t}$ of polyglycol and Table 6 for zinc flotation as $80 \mathrm{~g} / \mathrm{t}$ potassium amyl xanthate, $400 \mathrm{~g} / \mathrm{t}$ copper sulphate, $300 \mathrm{~g} / \mathrm{t}$ sodium silicate, $40 \mathrm{~g} / \mathrm{t}$ of polyglycol at rougher flotation stage.

Metallurgical balance. It is notable from the metallurgical balance of flotation tests summarized in Table 5 and Table 7 that two cleanings of the rougher concentrate and circulating of cleaning tailings back to subsequent cycle test have ensured a final lead and zinc concentrate

Table 7. Metallurgical balance for sphalerite flotation

\begin{tabular}{llllll}
\hline \hline Products of flotation & Weight & \multicolumn{3}{c}{ Assay \% } & \multicolumn{3}{c}{ Distribution\% } \\
& $(\%)$ & $\mathrm{Zn}$ & $\mathrm{Pb}$ & $\mathrm{Zn}$ & $\mathrm{Pb}$ \\
\hline Zinc re-cleaner concentrate & 10.16 & 55.63 & 0.32 & 80.28 & 1.05 \\
Zinc re-cleaner tailings & 2.99 & 14.32 & 1.40 & 6.08 & 1.35 \\
Zinc cleaner concentrate & 13.15 & 46.23 & 0.57 & 86.36 & 2.40 \\
Zinc cleaner tailings & 9.36 & 4.08 & 1.07 & 5.42 & 3.20 \\
Zinc rougher concentrate & 22.51 & 28.71 & 0.77 & 91.78 & 5.60 \\
Lead rougher concentrate & 7.97 & 4.38 & 35.40 & 4.96 & 90.38 \\
Bulk rougher tailings & 69.52 & 0.33 & 0.18 & 3.26 & 4.02 \\
Head sample & 100.0 & 7.04 & 3.12 & 100.0 & 100.0 \\
\hline \hline
\end{tabular}

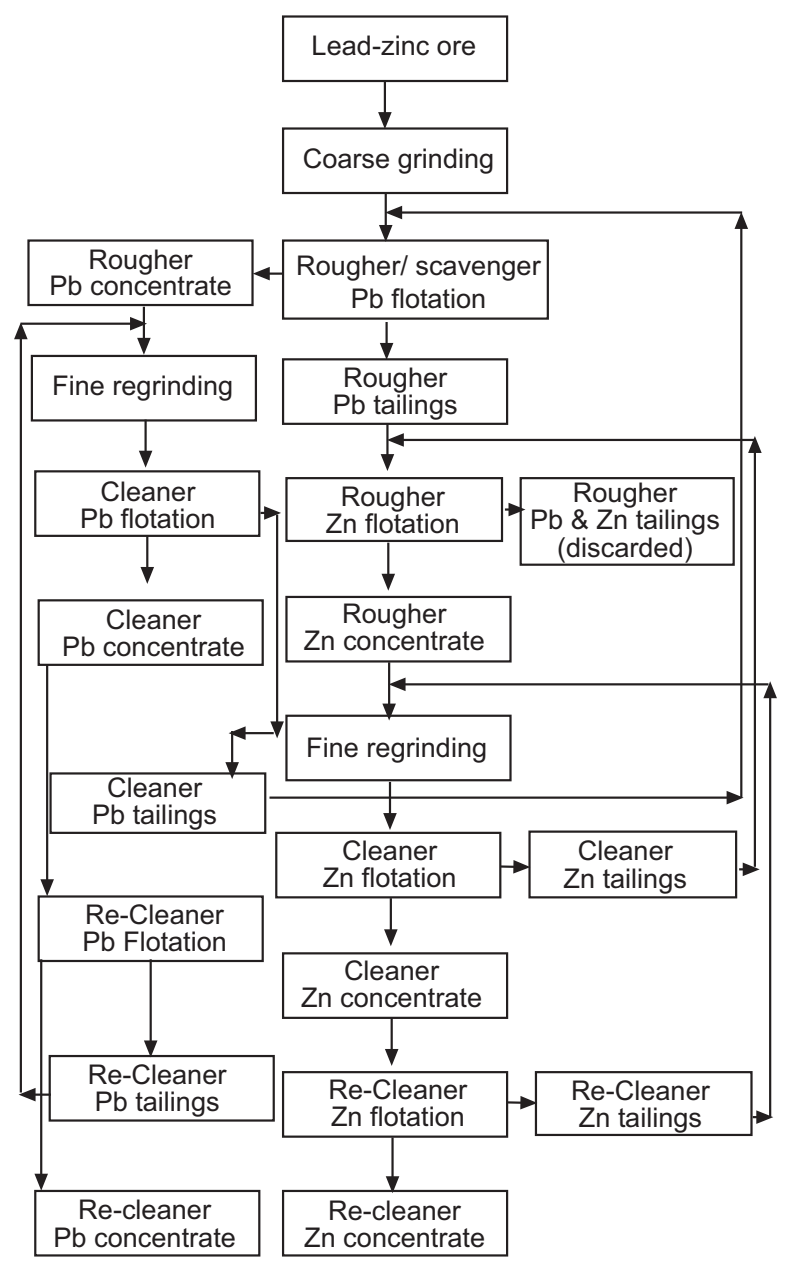

Fig. 13. Flow-sheet for the beneficiation low grade complex polymetallic lead-zinc ore of Duddar, (Lasbela) Balochistan, Pakistan

containing over $55 \%$ metal content with more than $80 \%$ recovery. Based upon these results, a flow sheet shown in Fig. 13 has been suggested for the beneficiation of Duddar lead-zinc ore. The flow sheet of developed process includes two stage grindings; first coarse and then fine, rougher-scavenger flotation, two cleanings and circulating of cleaning tailings to produce commercial grade lead and zinc concentrates.

The metallurgical balance of locked cycle flotation test at optimum conditions shown in Table 5 and 7 indicates that lead content of the investigated ore could be raised from $3.12 \% \mathrm{~Pb}$ to $35.40 \% \mathrm{~Pb}$ with $90.38 \%$ recovery and zinc content from $7.04 \% \mathrm{Zn}$ to $28.71 \% \mathrm{Zn}$ with $91.78 \%$ recovery at rougher flotation stage. The lead rougher concentrate was upgraded into lead cleaner 
concentrate assaying $58.62 \% \mathrm{~Pb}$ with $84.06 \%$ recovery and zinc rougher concentrate into zinc cleaner concentrates assaying $46.23 \% \mathrm{Zn}$ with $86.36 \%$ using additional quantity of reagents in the cleaner circuits. The cleaned concentrates were upgraded during a recleaner flotation. It is clear from the Table.7 that, the best grade lead concentrate containing $65.24 \% \mathrm{~Pb}$ can be obtained with a recovery of $81.32 \%$ and zinc concentrate containing $55.63 \% \mathrm{Zn}$ with a recovery of $80.28 \%$.

The detailed flotation studies conducted on the samples under different process conditions resulted in reasonably high recovery of lead and zinc bearing minerals for sulphide ore. The successful production of metallurgical grade lead and zinc concentrates in three step flotation shows the suitability of the technique applied for processing of this ore. The flotation tests have proved that this ore can be beneficiated into high-grade lead and zinc concentrates without pre-concentration step (Table 8). It is clear from the data of the foregoing tests that flotation process has reduced the gangue minerals present in ore significantly which greatly economize the extraction of respective metals.

Table 8. Final chemical analysis of lead and zinc concentrates

\begin{tabular}{lll}
\hline \hline Constituents & Lead concentrate (\%) & Zinc concentrate (\%) \\
\hline $\mathrm{Pb}$ & 65.24 & 0.32 \\
$\mathrm{Zn}$ & 1.08 & 55.63 \\
$\mathrm{Fe}$ & 6.78 & 6.40 \\
$\mathrm{~S}$ & 18.14 & 34.57 \\
$\mathrm{SiO}_{2}$ & 2.28 & 1.78 \\
$\mathrm{Al}_{2} \mathrm{O}_{3}$ & 1.53 & 1.12 \\
$\mathrm{BaO}$ & 0.61 & 0.44 \\
$\mathrm{CaO}$ & 0.50 & 0.62 \\
$\mathrm{MgO}$ & 0.03 & 0.02 \\
$\mathrm{Na} \mathrm{K}_{2} \mathrm{O}$ & 0.04 & 0.05 \\
$\mathrm{~K}_{2} \mathrm{O}$ & 0.01 & 0.01 \\
\hline \hline
\end{tabular}

\section{Conclusion}

X-Ray diffraction studies on Duddar lead-zinc ore show that it comprises of mainly galena and sphalerite as economic minerals, while the other are considered as associated gangue minerals. Chemical analysis shows that lead and zinc content of this ore is sufficient to exploit it on commercial scale to produce lead and zinc concentrates of required grade with acceptable recovery. The laboratory scale flotation studies have established that ore can be beneficiated to produce lead concentrate assaying $65.24 \% \mathrm{~Pb}$ and zinc concentrate assaying $55.63 \% \mathrm{Zn}$. It is concluded that grind size of $80 \%$ passing 200 mesh at rougher stage and 98\% passing 200 mesh at cleaning stages give the optimum results. The conditioning of pulp $\mathrm{pH}$ around 9 during lead flotation and 11 during zinc flotation must be maintained for best results. In addition, conditioning at pulp density of $30 \%$ and agitation speed of $1100 \mathrm{rpm}$ at rougher stage has advantages. The conditioning time for $5 \mathrm{~min}$ in case of lead and $15 \mathrm{~min}$ in case of zinc flotation is essential. The most satisfactory reagent combination used for lead flotation was found to be $70 \mathrm{~g} / \mathrm{t}$ potassium ethyl xanthate, $300 \mathrm{~g} / \mathrm{t}$ sodium silicate, $150 \mathrm{~g} / \mathrm{t}$ sodium cyanide, $30 \mathrm{~g} / \mathrm{t}$ of polyglycol and similarly for zinc flotation was $80 \mathrm{~g} / \mathrm{t}$ potassium amyl xanthate, $400 \mathrm{~g} / \mathrm{t}$ copper sulphate, $300 \mathrm{~g} / \mathrm{t}$ sodium silicate, $40 \mathrm{~g} / \mathrm{t}$ of polyglycol at rougher flotation stage. The higher grade concentrates are obtained after one regrinding and two cleaning operations. Both concentrates fall in the category of metallurgical and chemical grades and can be utilized for the economical extraction of metals as well as production of chemicals. It is recommended that the pilot plant scale tests should be performed on the basis of this bench scale study in order to prepare pre-investment economic feasibility and a commercial plant should be designed in the light of those results.

\section{Acknowledgement}

The authors are highly thankful to Director, Pakistan Mineral Development Corporation (PMDC) for providing lead-zinc ore. The authors are also grateful to Dr. Akhtar Ali Saleemi, Institute of Geology, University of the Punjab, for his co-operation in X-Ray diffraction analysis.

\section{References}

Ahmad, Z. 1978. Geology of mineral deposits of Balochistan, Pakistan. Records of the Geological Survey of Pakistan, 36:178.

Allen, R.M., Anwar, J. 1994. Geological setting of the Duddar zinc-lead deposits, an exploration model for Lasbela-Khuzdar belt. In: Proceedings of Second SEGMITE International Conference, pp.64-71, Karachi, Pakistan.

Atrafi, A., Hodjatoleslami, H., Noaparast, M. Shafaei, Z. Ghorbani, A., 2012. Implementation of flotation and gravity separation, to process Changarzeh sulfide-oxide lead ore. Journal of Mining \& Environment, 3: 79-87. 
Bulatovic, S.M. 2007. Handbook of Flotation Reagents: Chemistry, Theory and Practice: Vol.: Flotation of Sulfide Ores, pp. 20-22, Elsevier Science \& Technology Books Publisher: Amsterdam, Holland.

Bushell, C.H.G., Testut, R.J. 1985. SME Mineral Processing Hand Book, E. F. Milner (ed.), vol. 2, pp.1-7, Society of Mining Engineers Section 15, pp 1-7, New York, USA.

Crozier, R. D. 1992. Flotation Theory, Reagents and Ore Testing, pp. 245-246, Pergamon Press oxford, England, UK.

Day, A. (ed.), 2002. Mining Chemicals Handbook, Revised Edition, pp: 140-143, Cytec Industries Inc. West Paterson, New Jersey, USA.

Fairweather, M.J. 2005. The Sullivan concentrator, the last and (the best) 30 years. In: Proceedings of the Centenary of Flotation Symposium, G. Jameson, (ed.), pp. 835-844, The Australasian Institute of Mining and Metallurgy, (Aus. IMM) Brisbane, Australia.

Gaudin, A.M. 2001. Principles of Mineral Dressing, 376 pp. $15^{\text {th, }}$ edition, Tata McGraw Hill Publishing Company Ltd, New Delhi, India.

Hidayet, C., Cahit, H., Taki, G. 2002.Collectorless flotation of lead and zinc sulphide from Derekoy Ore Deposit. Physicochemical Problems of Mineral Processing, 36: 197-208.

Jain, S.K. 2001. Mineral Processing, pp. 453-456, $2^{\text {nd }}$ edition, CBS Publisher and Distributor, New Delhi, India.

Jones, G.V., Sajjad, A. 1994. Duddar Zn-Pb-Fe-Ba mineralization. In: Proceedings of Second SEGMITE International Conference, pp. 58-63, Karachi, Pakistan.

Kashani, A.H.N, Rashchi, F. 2008. Reagents in zinc recovery from $\mathrm{Pb}$-flotation tailings of Dandy mineral processing plant. Journal of Faculty of Engineering, 41: 1103-1110.

Kazmi, K.R., Gohar, R. A., Anwar, M. S. 2000. Flotation characteristics of lead-zinc ore from Besham, District Swat, NWFP, Pakistan. Pakistan Journal Scientific and Industrial Research, 43: 319-323.

Keqing, F.A., Miller, J. D., Tao, J., Guang-hui, L. 2005. Sulphidization flotation for recovery of lead and zinc from oxide-sulfide ores. Transactions of Nonferrous Metals Society of China, 15: 11381144.
Khoshdast, H., Sam, A. 2011. Flotation frothers: review of their classifications, properties and preparation. The Open Mineral Processing Journal, 4: 25-44.

Li, M.M., Zhang, Q.D. 2012. Experimental study on flotation process conditions of lead-zinc ore. Advance Materials Research, 454:183-188.

Melo, F., Laskowski, J.S. 2006. Fundamental properties of flotation frothers and their effect on flotation. International Journal of Mineral Processing, 19: 766-773.

Milena, K. 2011. Depression of pyrite mineral with cyanide and ferrous/ferric salts. Underground Mining Engineering, 19: 149-155.

Rao, S. R. 2004. Surface Chemistry of Froth Flotation, vol. 1, pp. 58-63, $2^{\text {nd }}$ edition, Kluwer Academic, Plenum Publishers, New York, USA.

Silvestre, M.O., Pereia, C. A., Galary, R., Peres, A.E.C. 2009. Dispersion effect on a lead-zinc sulphide ore flotation. Minerals Engineering, 22: 752-758.

Singh, R., Rao, D.S., Sinha, N., Banerjee, B., Bhattacharyya, K.K. 2009. Mineralogical and flotation characteristics of lead-zinc ore with a particular reference to effects of oxidation. Journal of Metallurgy and Materials Science, 51: 205-213.

Singh, R., Banergee, B., Srivastava, J.P., 2004. Effect of process parameters on selective flotation of leadzinc ore, In: International Seminar on Mineral Processing Technology, G. V. Rao, Vibhuti N. Misra, (eds.), pp. 425-432, Jamshedpur, India.

Tan, S.N., Pugh, R.J., Fornasiero, D., Sedev, R., Ralston, J. 2005. Foaming of polypropylene glycols and glycol/MIBC mixtures. Minerals Engineering, 18: 179-188.

Wills, B.A., Napier-Munn, T. J. 2006. An introduction to the practical aspects of ore treatment and mineral recovery, In: Wills' Mineral Processing Technology, pp.332-344, $7^{\text {th }}$ edition, Butterworth-Heinemann Publishers, Oxford, UK.

Yuan, Z., Yu, X., Liu, L., Wang, C. 2012. Flotation separation of high sulphure lead-zinc ore. Advance Materials Research, 454: 205-209.

Zaigham, N.A. 1994. Gravity models for exploration of the lead-zinc sulphide bodies in Duddar area, Lasbela district, Balochistan, Pakistan. In: Proceedings of Second SEGMITE International Conference, pp. 128-134, Karachi, Pakistan. 